\title{
A spindle cell carcinoma presenting with osseous metaplasia in the gingiva: a case report with immunohistochemical analysis Naoki Katase ${ }^{1}$, Ryo Tamamura1, Mehmet Gunduz'1, Jun Murakami ${ }^{2}$, Jun- Ichi Asaumi², Goichi Tsukamoto ${ }^{3}$, Akira Sasaki ${ }^{3}$ and Hitoshi Nagatsuka*1
}

\author{
Address: ${ }^{1}$ Department of Oral Pathology and Medicine, Graduate School of Medicine, Dentistry and Pharmaceutical Sciences, Okayama \\ University, Okayama, 700-8525, Japan, ${ }^{2}$ Department of Oral and Maxillofacial Radiology, Graduate School of Medicine, Dentistry and \\ Pharmaceutical Sciences, Okayama University, Okayama, 700-8525, Japan and ${ }^{3}$ Department of Oral and Maxillofacial Surgery and \\ Biopathological Science, Graduate School of Medicine, Dentistry and Pharmaceutical Sciences, Okayama University, Okayama, 700-8525, Japan \\ Email: Naoki Katase - gmd17099@cc.okayama-u.ac.jp; Ryo Tamamura - tamamura@md.okayama-u.ac.jp; \\ Mehmet Gunduz - mgunduz@md.okayama-u.ac.jp; Jun Murakami - jun-m@md.okayama-u.ac.jp; Jun-Ichi Asaumi - asaumi@md.okayama- \\ u.ac.jp; Goichi Tsukamoto - gtsuka@md.okayama-u.ac.jp; Akira Sasaki - asasaki@md.okayama-u.ac.jp; Hitoshi Nagatsuka* - jin@md.okayama- \\ u.ac.jp \\ * Corresponding author
}

Published: I December 2008

Head \& Face Medicine 2008, 4:28 doi:10.1 186/1746-160X-4-28

This article is available from: http://www.head-face-med.com/content/4/I/28

(C) 2008 Katase et al; licensee BioMed Central Ltd.

This is an Open Access article distributed under the terms of the Creative Commons Attribution License (http://creativecommons.org/licenses/by/2.0), which permits unrestricted use, distribution, and reproduction in any medium, provided the original work is properly cited.
Received: I August 2008

Accepted: I December 2008

\begin{abstract}
Background: Spindle cell carcinoma $(\mathrm{SpCC})$ is a rare, high malignant variant of squamous cell carcinoma (SCC), which shows biphasic proliferation of conventional SCC component and malignant spindle shape cells with sarcomatous appearance.

Methods: A case of Spindle cell carcinoma with bone-like calcified materials, occurring at the mandibular molar region of $7 \mathrm{I}$-years-old Japanese male patient was presented with gross finding, histological findings and MRI image. To identify the characteristics of the bone-like materials, immunohistochemistry were performed.
\end{abstract}

Results: Histologically, the cancer cells were composed of spindle cells and epithelial cells which form nests with prominent keratinization. Histological findings showed typical histology of the SpCC, however, as an uncommon finding, spatters of calcified, bone-like materials were observed in between the cancer cells. Immunohistochemistry revealed that cancer cells were positive for cytokeratins and vimentin to a varying degree and negative for Desmin, S-100, Osteopontin, BMP2 or BMP-4. These findings implied that the calcified materials were formed by metaplasia of the stromal cells.

Discussion: Bone-like materials formation by osseous and/or cartilaginous metaplasia of the stroma in the carcinoma has been reported. However, the detailed mechanism of these metaplasia and affection on the clinical feature, prognosis and therapies are not well established. In summary, we presented an unique case of SpCC, which has not been described in the literature.

\section{Background}

Spindle cell carcinoma (SpCC), also known as sarcomatoid carcinoma or pseudosarcoma, of head and neck is a rare neoplasm. SpCC is known as a high malignant variant of squamous cell carcinoma, which is composed of conventional squamous cell carcinoma component, 
either in-situ and/or invasive and malignant spindle component with sarcomatous appearance. Although it is generally accepted that SpCC is a monoclonal epithelial neoplasm [1-5], and the sarcomatous components are derived from squamous epithelium with divergent mesenchymal differentiation [6], the diagnosis, classification and management of this tumor infrequently may become subject matter deluded of its histological variety in sarcomatous components. These sarcomatous components commonly resemble to fibrosarcoma or malignant histiocytoma $[7,8]$, and while rare, foci resembling to chondrosarcoma and/or osteosarcima differentiation may be observed [9].

This is a case report of a spindle cell carcinoma of gingival mucosa presenting with bone-like calcified materials.

\section{Case presentation}

A 71-year-old Japanese male patient was referred to the Okayama University Hospital, complaining the swelling at the left side of the mandibular molar region. The lesion was $44 \times 29 \mathrm{~mm}$ in size, exophytic with rough and irregular surface. The patient's medical and family histories were unremarkable.

Clinically, the lesion was elastic soft and fragile, and the surface of the lesion was ulcerated [Fig. 1]. The margin of the lesion was clear, and MRI scan revealed no invasion into circumjacent tissues [Fig. 2]. Moreover, invasion into the mandibular bone was not prominent on the CT images. With the suspicion of poorly differentiated squamous cell carcinoma from the biopsy, surgical resection

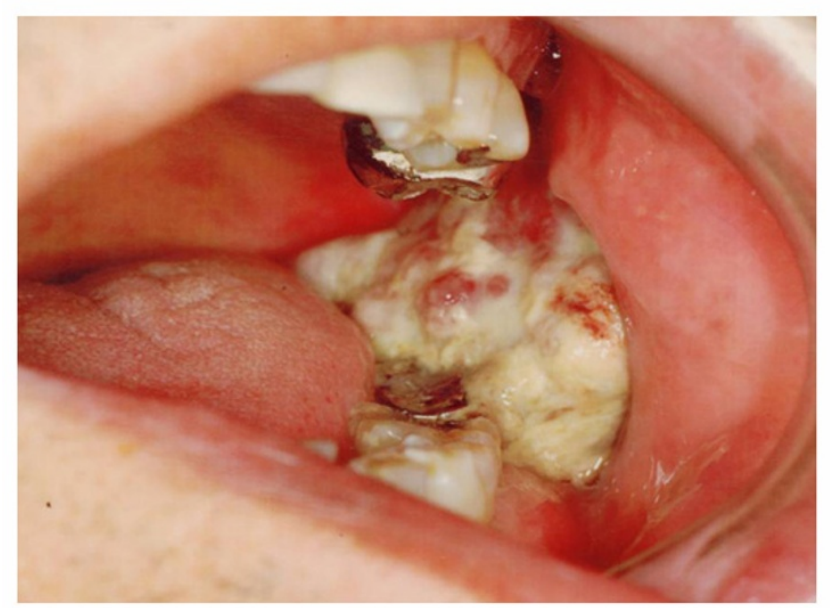

\section{Figure I}

Gross finding of the tumor. Intraoral examination showed exophytic, polypoid mass with irregular surface in the mandibular molar region.

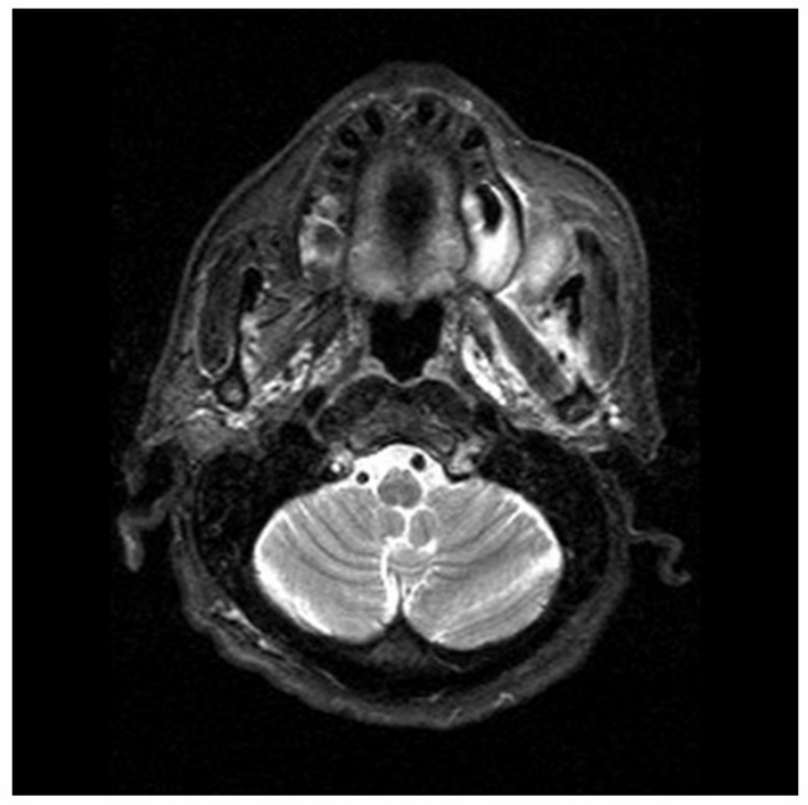

Figure 2

Axial MRI imaging of the tumor. The margin of the lesion was clear, no invasion was observed.

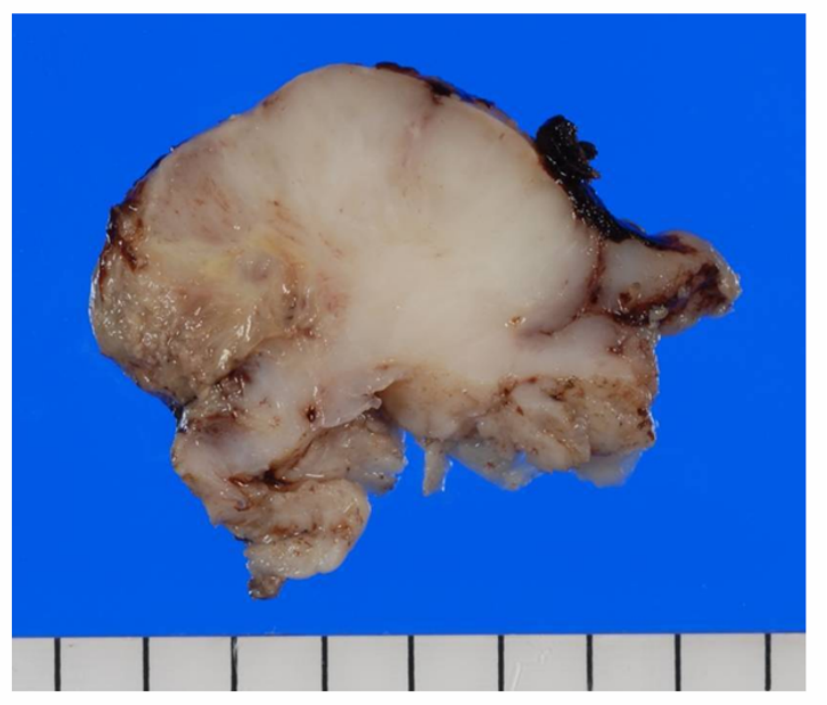

\section{Figure 3}

Macroscopic image of the tumor. The lesion was a fragile mass with ulcerated surface. The cut surface was grayishwhite in color, myxoid or lobular pattern in some areas. 
with neck dissection was performed. The lesion was a fragile mass, grayish-white in color [Fig. 3].

No tumor cells were observed around the surgical margin, and lymph node metastasis was not observed. No recurrence or metastasis was detected since surgery so far.

Histologically, the tumor showed biphasic appearance. The bulk of the tumor was composed of invasive, spindle shape cells, which arranged irregularly with bundle formation resembling to fibrosarcoma. Together with the spindle shape tumor cells, proliferation of polygonal epithelial cells were observed, forming tumor nests with distinct keratinization similar to cancer nest observed in well differentiated squamous cell carcinoma. In some areas, spindle shape cells were transitional to the epithelial cancer nest-like structure. The stromal cells were intermingled with the spindle shape cells, showing myxoid appearance.
In some areas, spatters of calcified, bone-like materials were observed in between the malignant spindle cells, which showed osteosarcimatous appearance [Fig. 4]. From all these histological findings, the lesion was diagnosed as spindle cell carcinoma (SpCC) with osteosarcomatous differentiation.

To confirm the diagnosis, immunohistochemistry was performed according to avidin-biotin-peroxidase complex $(A B C)$ method. The detail of the antibodies used for immunohistochemistry is summarized in Table 1.

Immunohistochemistry revealed that spindle shape cells showed positive reaction for cytokeratins, vimentin, negative reaction for S-100 protein and desmin, squamous cell carcinoma-like nest forming epithelial components showed positive reaction for cytokeratins, both low- and high-molecular weight, negative for vimentin, S-100 and
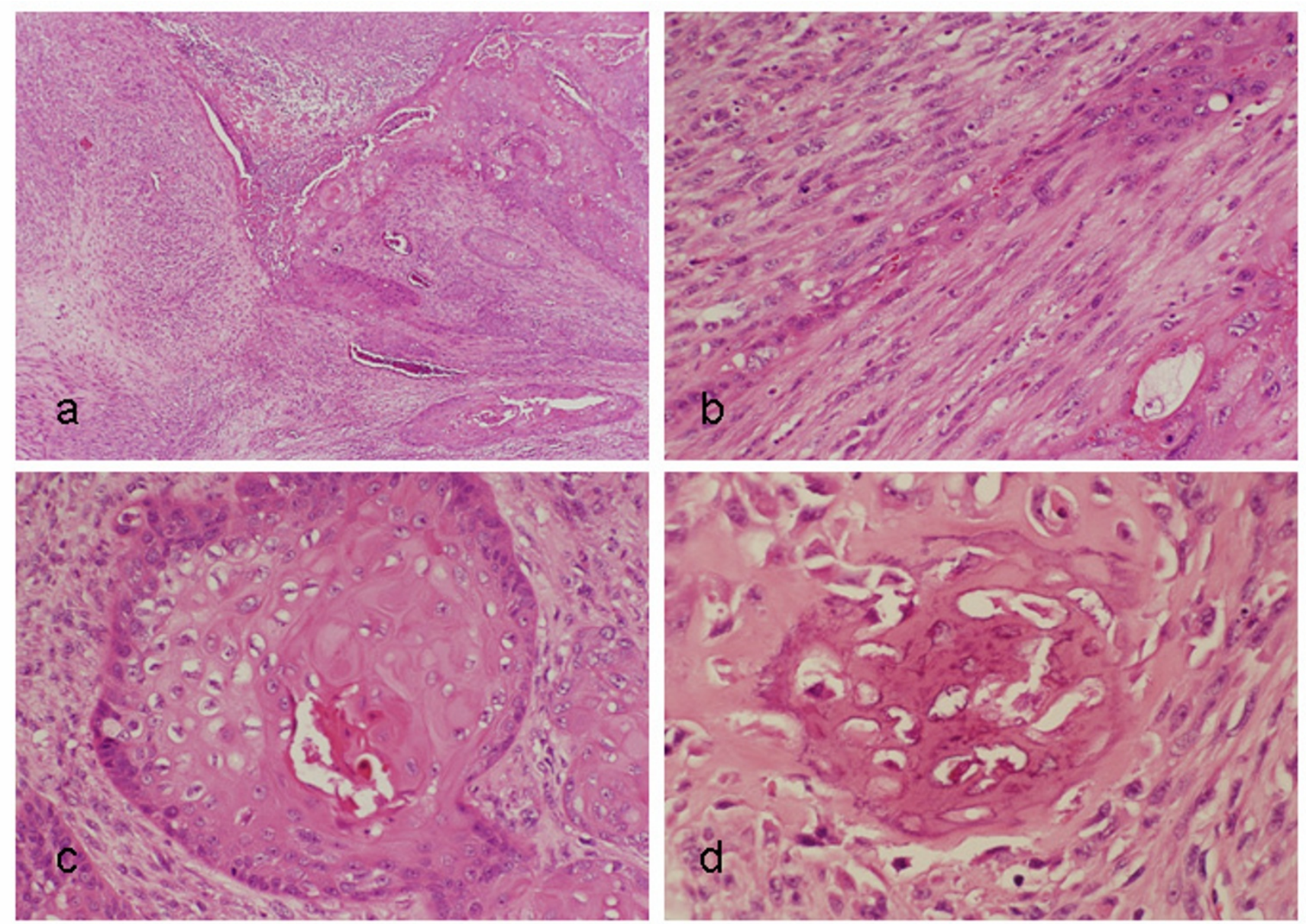

\section{Figure 4}

Histological findings. (a) The cancer cells were composed of spindle cell component and epithelial component. (b) Transition of spindle cells into epithelial component was observed. (c) Conventional squamous cell carcinoma components presenting with keratinization were also observed. (d) Spatters of calcified materials with bone-like appearance were observed. 
Table I: Antibodies used for the present case

\begin{tabular}{|c|c|c|c|}
\hline \multirow[t]{2}{*}{ Antibody } & \multirow[t]{2}{*}{ Source } & \multicolumn{2}{|c|}{ Result } \\
\hline & & Spindle cells & Epithelial cells \\
\hline Cytokeratin AEI/AE3 & DAKO(USA) & + & + \\
\hline Cytokeratin 8 & Roche Diagnostics (Germany) & $+/-$ & + \\
\hline Cytokeratin 19 & Novocastra (UK) & $+/-$ & + \\
\hline Vimentin & DAKO(USA) & + & - \\
\hline Desmin & DAKO(USA) & - & - \\
\hline S- 100 & Nichirei (Japan) & - & - \\
\hline aSMA & DAKO(USA) & $+/-$ & $+/-$ \\
\hline Osteopontin & IBL (Japan) & - & - \\
\hline BMP-2 & Santa Cruz (USA) & - & - \\
\hline BMP-4 & Santa Cruz (USA) & - & - \\
\hline $\mathrm{Ki}-67$ & DAKO (USA) & & \\
\hline
\end{tabular}

aSMA: alpha smooth muscle actin, BMP: bone morphogenetic protein +: positive, +/-: focally positive, -: negative

desmin. Alpha smooth muscle actin ( $\alpha$ SMA) was vaguely positive in both spindle shape cells and epithelial cells. The cells around bone-like calcified materials showed positive reaction for low-molecular weight cytokeratin and vimentin, osteopontin was only positive in the bone matrix-like area. Cancer cells did not show positive reaction for osteopontin, bone morphogenetic protein (BMP) -2 or BMP- 4 . Ki- 67 index was around $30 \%$ at a maximum, but that of the cells around bone-like materials was lower [Fig. 5]. Thus the bone-like materials were considered as metaplastic bone formation.

\section{Discussion}

SpCC is a rare variant of squamous cell carcinoma. Its most frequently affected sites is larynx, however, it may infrequently occur in various organs; gingiva $[2,10]$, tongue $[11,12]$, upper aerodigestive tract including hypopharynx and nasal cavity $[6,13,14]$, esophagus, skin and breast [15].

It is generally understood that the diagnosis of SpCC requires the demonstration of both components [16]. In accord with this criterion, typical histology of SpCC was observed in the present case, which was composed of conventional squamous cell carcinoma component and spindle shape cells with sarcomatous appearance.

However, the existence of bone-like calcified materials was the uncommon, controversial finding for SpCC in oral mucosa. To the best of our knowledge, this finding was not described in previous report. In the immunohistochemical examination, both epithelial component and spindle shape cell component showed positive reaction for cytokeratins to a varying degree, but vimentin positive cells were limited to the spindle shape cell component. These results were consistent to the previous reports
$[1,14,17-19]$. The cells around the materials were vimentin-positive low activity cells, and cancer cells did not show positive reaction for neither BMP-2 nor BMP-4, which indicates these materials were formed by mesenchymal metaplasia of the stromal cells, but not by the tumor cells itself.

Although the incidence of osseous metaplasia is rare finding in oral SpCC, it is occasionally observed in that of larynx [8]. While also rare, the formation of bone-like and/ or cartilage-like materials by the metaplasia of stromal cells is often reported in various kind of carcinomas, such as laryngeal cancer [20], esophageal cancer [21,22], colon cancer [23-25], lung cancer [26], and breast cancer [27]. The histogenesis of the osseous and/or cartilaginous metaplasia in the carcinoma has been come up to debate so far. The biological mechanism of these metaplastic changes is considered to be caused by stromal activation associated with human-host interface [20]. Although some report implies the formation of these materials is related to radiation therapy [21], the mechanism of stromal metaplasia is still unclear. Moreover, the affection of these metaplastic bone or cartilage on the clinical features, prognosis, and response to radiation therapy or chemotherapy are not well established.

\section{Conclusion}

In summary, we reported a unique of SpCC with calcified bone-like materials in the gingiva, which is a very rare case in the literature.

\section{Consent}

Written informed consent was obtained from the patient for publication of this case report and any accompanying images. A copy of the written consent is available for review by the Editor-in-Chief of this journal. 

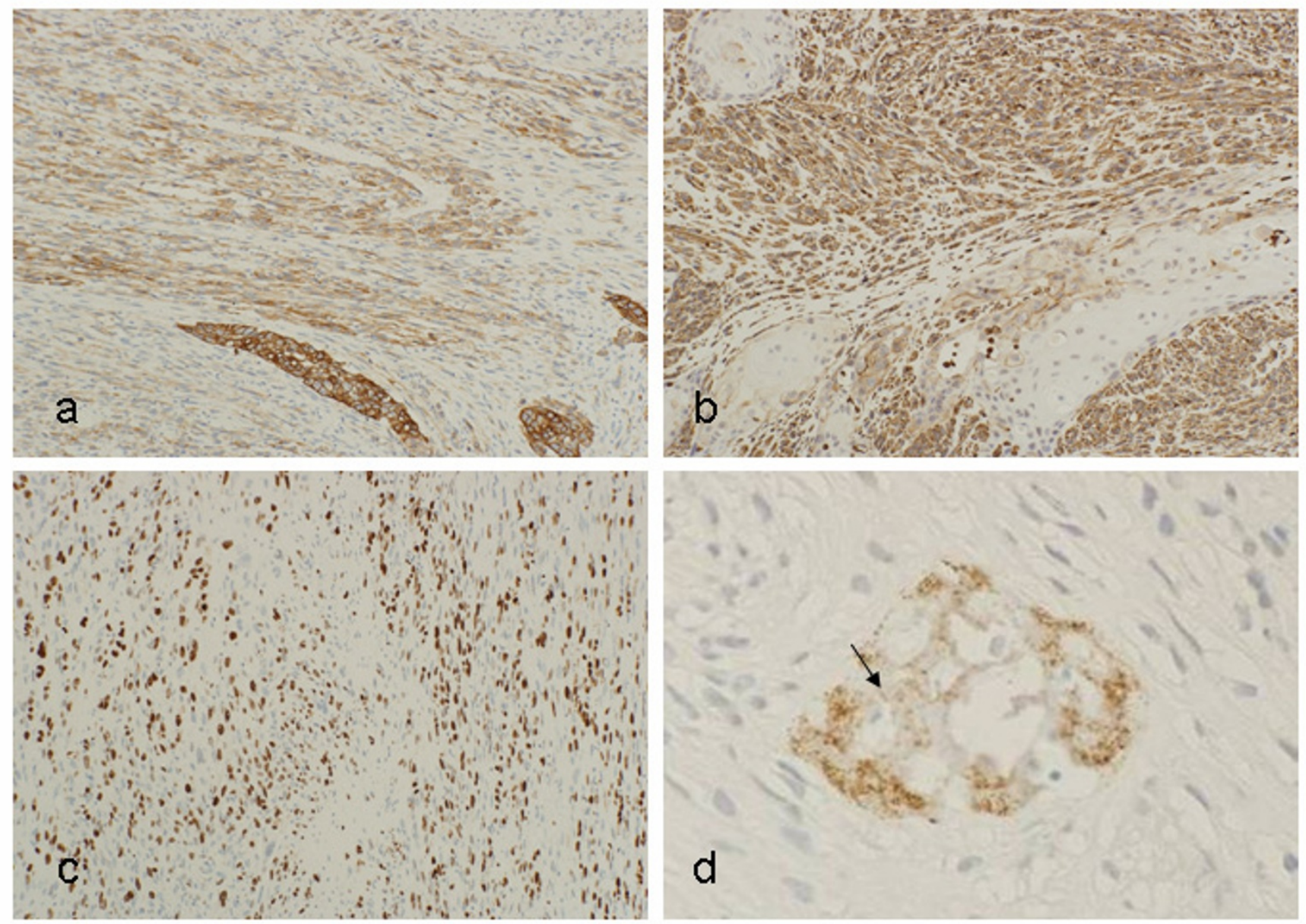

\section{Figure 5}

Immunohistochemistry. (a) Cytokeratin AEI/AE3 was positive both in spindle shape cells and epithelial nests. (b) Vimentin was only positive in spindle shape cell component, while it is negative in the epithelial nests. (c) Ki-67 index of the cancer cells was $>30 \%$. (d) The matrix of the calcified materials (arrows) showed positive reaction for osteopontin, while cancer cells did not.

\section{Abbreviations}

SpCC: Spindle cell carcinoma

\section{Competing interests}

The authors declare that they have no competing interests.

\section{Authors' contributions}

NK, HN and RT carried out the case study, discussed and reviewed the literature and prepare the manuscript. GT and JM contributed to the collection of clinical and/or radiological data and discussion. GM, JA and AS participated in review process and carried out critical revision of the manuscript.

\section{Acknowledgements}

The work was supported by Grant-in-Aid for Scientific Research (B) No.20791337 and (C) No.19592109 from the Japanese Ministry of Educa- tion, Culture, Sports, Science and Technology. Written consent for publication was obtained from the patients or their relative. The authors would like to thank Ms. Kazuko Funakoshi for the expert technical assistance in histological preparations.

\section{References}

I. Takata T, Ito H, Ogawa I, Miyauchi M, ljuhin N, Nikai H: Spindle cell squamous carcinoma of the oral region. An immunohistochemical and ultrastractual study on the histogenesis and differential diagnosis with a clinicopathological analysis of six cases. Virchows Arch 1991, 419:177-182.

2. Leventon GS, Evans HL: Sarcomatoid squamous cell carcinoma of the mucous membranes of the head and neck: a clinicopathological study of 20 cases. Cancer 198I, 48:994-1003.

3. Guarino M, Tricomi P, Giordano F, Cristofori E: Sarcomatoid carcinomas: pathological and histopathogenetic considerations. Pathology 1996, 28:298-305.

4. Thompson L, Chang B, Barsky SH: Mompclonal origins of malignant mixed tumors (carcinosarcomas). Evidence for a divergent histogenesis. Am J Surg Pathol 1996, 20:277-285.

5. Torenbeek R, Hermsen MA, Meijer GA, Baak JP, Meijer CJ: Analysis by comparative genomic hybridization of epithelial and spin- 
dle cell components in sarcomatoid carcinoma and carcinosarcoma: histogenetic aspects. J Pathol 1999, 189:338-348.

6. Batsakis JG, Suarez P: Sarcomatoid carcinomas of upper aerodigestive tracts. Adv Anat Pathol 2000, 7:282-293.

7. Lewis JE, Olsen KD, Sebo TJ: Spindle cell carcinoma of the larynx: review of 26 cases including DNA content and immunohistochemistry. Hum Pathol 1997, 28:664-673.

8. Thompson LD, Wieneke JA, Miettinen M, Heffner DK: Spindle cell (sarcomatous) carcinoma of the larynx: a clinicopathologic study of 187 cases. Am J Surg Pathol 2002, 26: 153-170.

9. Lambert PR, Ward PH, Berci G: Pseudosarcoma of the larynx: a comprehensive analysis. Arch Otolaryngol 1980, 106:700-708.

10. Munakata R, Cheng J, Nakajima T, Saku T: Spindle cell carcinoma of the gingiva: report of an autopsy case. J Oral Pathol Med 1998, 27(4): $180-184$.

II. Sherwin RP, Strong MS, Vaughn CW Jr: Polypoid and junctional squamous cell carcinoma of the tongue and larynx with spindle cell carcinoma ("pseudosarcoma"). Cancer 1963, 16:5I-60.

12. Chen YK, Lin CC, Chen CH, Yan YH, Lin LM: Spindle cell carcinoma of the tongue: Case report and immunohistochemistry study. Oral Med Pathol 1998, 3:5 I-54.

13. Altrabulsi B, Carrizo F, Luna MA: Spindle basaloid squamous carcinoma of the upper aerodigestive tract: immunohistochemical and clinicopathological study of three cases. Ann Diagn Pathol 2006, 10: I 49-153.

14. Ellis GL, Langloss JM, Heffner DK, Hyams VJ: Spindle-cell carcinoma in the upper aerodigestive tract. An immunohistochemical analysis of 2 I cases. Am J Surg Pathol 1987, I I:335-342

15. Su HH, Chu ST, Hou YY, Chang KP, Chen CJ: Spindle cell carcinoma of the oral cavity and oropharynx: Factors affecting outcome. J Chin Med Assoc 2006, 69:478-483.

16. Banes L, Eveson JW, Reichart P, Sidransky D, Eds: World Health Organization Classification of Tumors. Pathology and Genetics of Head and Neck Tumors. IARC Press: Lyon 2005:I27.

17. Meijer JW, Ramaekers FC, Manni JJ, Slooff JJ, Aldeweireldt J, Vooys GP: Intermediate filament of proteins in spindle cell carcinoma of the larynx and tongue. Acta Otolaryngol 1988, 106:306-313.

18. Slootweg PJ, Roholl PJ, Muller H, Lubsen H: Spindle cell carcinoma of the oral cavity and larynx. Immunohistochemical aspects. J Craniomaxillofac Surg 1989, 17:234-236.

19. Gupta R, Singh S, Hedau S, Nigam S, Das BC, Singh I, Mandal AK: Spindle cell carcinoma of head and neck: an immunohistochemical and molecular approach to its pathogenesis. J Clin Pathol 2007, 60:472-475.

20. Marioni G, Altavilla G, Marino F, Marchese-Ragona R, Lelli-Mami G, Staffieri A: Squamous cell carcinoma of the larynx with osteosarcima-like stromal metaplasia. Acta Otolaryngol 2004, 124:870-873.

21. Sugai T, Oikawa $M$, Uesugi N, Habano W, Jiao YF, Nakamura $S$, Hatakeyama S, Suhara M, Hatafuku K: Esophageal squamous cell carcinoma characterized by extensive chondroid differentiation. Pathol Int 2000, 50:5I4-5I9.

22. Kwatra KS, Prabhakar BR, Jain S, Grewal JS: Sarcomatoid carcinoma of the esophagus with extensive areas of osseous differentiation: a case report. Indian J Pathol Microbiol 2003, 46:49-5I.

23. Alper M, Akyürek N, Patiroğlu TE, Yüksel O, Belrenli O: Heterotopic bone formation in two cases of colon carcinoma. Scand J Gastroenterol 2000, 35:556-558.

24. Ansari MQ, Sachs IL, Max E, Alpert LC: Heterotopic bone formation in rectal carcinoma. Case report and literature review. Dig Dis Sci 1992, 37:1624-1629.

25. Kypson AP, Morphew E, Jones R, Gottfried MR, Seigler HF: Heterotopic ossification in rectal cancer: Rare finding with a novel proposed mechanism. J Surg Oncol 2003, 82:132-136.

26. Hara H, Iwabuchi K, Shinada J, Yoshimura H, Kameya T: Pulmonary adenocarcinoma with heterotopic bone formation. Pathol Int 2000, 50:910-913.

27. Kijima $Y$, Umekita $Y$, Yoshinaka $H$, Owaki T, Sakamoto A, Yashida $H$, Aikou T: A case of breast carcinoma with cartilaginous and osseous metaplasia. Breast Cancer 2006, 13:214-219.

\footnotetext{
Publish with Biomed Central and every scientist can read your work free of charge

"BioMed Central will be the most significant development for disseminating the results of biomedical research in our lifetime. " Sir Paul Nurse, Cancer Research UK

Your research papers will be:

- available free of charge to the entire biomedical community

- peer reviewed and published immediately upon acceptance

- cited in PubMed and archived on PubMed Central

- yours - you keep the copyright

Submit your manuscript here:

http://www.biomedcentral.com/info/publishing_adv.asp

BioMedcentral
} 